\title{
Benefit, Monitoring \& Evaluation System: A Case Study of Malaysian Technical Education System
}

\author{
Aziz Deraman \\ Universiti Kebangsaan, Malaysia \\ a.d@pkrisc.cc.ukm.my \\ M. Naim Yaakub \\ Ministry of Education, Malaysia
}

\author{
Syahrul Fahmy \\ Universiti Kebangsaan, Malaysia \\ stahmy@taninet.com.my \\ A. Aziz Jemain \\ Universiti Kebangsaan, Malaysia
}

naim@iptek.moe.gov.my

azizi@pkrisc.cc.ukm.my

\begin{abstract}
This paper presents a case study of the Malaysian technical education system. The Technical and Vocational Department (TVED) is designated to prepare skilled technical and intelligent workforce to Malaysia in order to meet the goals of Vision 2020. For that reason, a web-based management support system is proposed to TVED for its planning, management and decision-making activities. e-BME is a system for education monitoring and evaluation by means of establishing internal and external efficiency indicators. e-BME would receive input mainly from Technical and Vocational Education (TVE) schools and graduates. There are four types of reports that are generated by the system: Management, Financial, Research and Planning. TVED could use these reports in its policy and decision-making activities. This system promotes faster data collection, higher integrity of generated information and a systematic channel for distribution of reports.
\end{abstract}

Keywords: Education Monitoring, Education Evaluation, Internal Efficiency, External Efficiency, Management Support System.

\section{Introduction}

Over the course of human history, education has appeared in many forms, both formal and informal. Education can be defined as 'the knowledge or skill obtained or developed by a learning process'. Today, as more and more companies and countries go global, specific knowledge and skill sets are needed in order to compete aggressively in the new market. Education and knowledge are becoming more important especially in this era of electronic commerce and borderless marketing.

Education can be categorized to many classifications according to fields of discussion. Some classifications of education would be primary, secondary, higher, continuing and special education. Technical education is another category of education that prepares students for jobs in technology fields. Such jobs lie between skilled crafts and engineering or scientific professions (Robert 1970; Rouse 1997).

Material published as part of these proceedings, either on-line or in print, is copyrighted by Informing Science. Permission to make digital or paper copy of part or all of these works for personal or classroom use is granted without fee provided that the copies are not made or distributed for profit or commercial advantage AND that copies 1) bear this notice in full and 2) give the full citation on the first page. It is permissible to abstract these works so long as credit is given. To copy in all other cases or to republish or to post on a server or to redistribute to lists requires specific permission from the publisher atpublisher@intormingscience.org
The objective of technical education is to give students a broad competence in a given field of applied science. The students are provided with sufficient background knowledge so that he or she can start a job with a brief orientation period and quickly take on full responsibilities. The curriculum in technical education normally includes courses in four classifications: basic science and related mathematics, technical specialty courses, commu- 
nications courses, and human relations and social studies.

Formal technical education in Malaysia is offered by Technical and Vocational Education schools (TVE) (Ayob \& Sulaiman 2001). These secondary schools are under the purview of the Technical and Vocational Education Department (TVED), a department under the Ministry of Education. Technical education is a two-year program where students will sit for the Malaysian Certificate of Education (SPM) examination and eventually continue their studies to various institutes of higher learning.

Vocational education, on the other hand, provides specific education and training programs to students for acquiring certain skills. Upon completion of this two-year program, students will sit for Malaysian Certificate of Vocational Education (SPMV). From there onwards, students can further their studies to polytechnics institutes or go into the job market immediately after graduation.

The Malaysian government is trying to shift its economy from a production-based economy to a knowledge-based economy (K-economy). Therefore, it is crucially important for Malaysia that the education and skills development programs are tailored to meet the needs of the labor industry. As such, TVED is designated to prepare skilled technical and intelligent workforce to Malaysia in meeting the goals of Vision 2020 (Ramlee et al. 2001; Ramziah et al. 2001).

Preparing for such an important task, TVED requires vast and critical information from various entities. Resources, such as human, financial and capital, need to be carefully planned and managed. Information on students, teachers and graduates need to be gathered and analyzed. Particular skill requirements from the industry need to be identified and appropriate adjustment to the current education system need to be carried out in order for TVED to fulfill its responsibility. Therefore, the Benefit, Monitoring and Evaluation or BME project has been carried out to accommodate TVED's information need.

This paper will propose a web-based system to support TVED in its planning, managing and decisionmaking activities. This computerized management support system is crucial for every aspect of TVED's management requirements. The system would ensure faster data collection, higher integrity of generated information and systematic distribution of management reports.

\section{Benefit, Monitoring and Evaluation in Education}

There are three important factors in planning and managing the education system namely benefit, monitor and evaluation. These factors may affect five distinct yet related entities: the education governance, education institution, student, graduate and the labor industry.

Benefit is the expected end result of any education system. In the case of Malaysia, benefit would be 'to ensure sufficient supply of skilled workforce to the labor industry'. Benefit affects the education governance, as it is responsible for setting the target for education system.

Monitoring is a process of scanning the internal and external education environment that affect the desired benefit in the long run. With regards to Malaysia, this means identifying required skills that should be acquired by worker; anticipating human resource requirement by various industries and planning necessary expenditure of current schools or establishing new ones to accommodate the growing number of students.

Success of the monitoring process is normally determined through a rigorous evaluation process. According to Ee (1991), evaluation in education is a process of using quantitative and qualitative data to measure a specific parameter for its acceptance in decision-making activites. Other similar definitions can also be found in Glaser (1992), Mok (1996), and Robiah (1994). Therefore, in the context of BME, evaluation is the academic assessment of students and the education system. Students are evaluated to ensure that they are progressing (academically) as expected. Education system is evaluated to ensure it meets the industry demands for specific skill and knowledge sets. Among the components evaluated in BME include academic examination results and the quality of graduates. 


\section{Computer-Based BME Model}

This section will discuss a BME model for the Malaysian TVE system. Discussion covers BME modeling, its requirement definitions and a computer-based model for Malaysian BME.

\section{BME Modeling}

Before discussing the model of BME system, it is important to identify the entities involved in the education system in Malaysia. These entities, as discussed, comprise of five namely education governance, education institution, student, graduate and the labor industry.

Education Governance in Malaysia is the responsibility of Ministry of Education (MOE). Technical education, the focus of this paper, is under the purview of TVED, a department under MOE. TVED has four divisions: Management, Finance, Planning and Research.

There are a quite a number of technical Education Institutions in Malaysia such as technical schools, vocational schools, polytechnics, public and private training institutions (i.e. German-Malaysian Institute, Malaysian French Institute and Japan-Malaysian Technical Institute). However, the focus of this paper is on secondary technical education and therefore, only TVE schools will be taken into consideration.

Student and Graduate are the current and ex-students of TVE schools respectively. There are more than 100 TVE schools across Malaysia. Labor Industry refers to the companies that employ TVE graduates.

\section{BME Requirement Definitions}

BME is a monitoring and evaluation system for technical education. We have identified the entities of the system. Next, would be to identify critical data and information needs. In the case of Malaysia, the requirement definitions were established by means of brainstorming sessions, fact-finding activities and conformation interviews with various levels of MOE personnel especially TVED. The requirement definition is categorized into four categories namely management, finance, research and planning. This classification is purely based on the divisions at TVED. Examples of these requirement definitions can be found in Appendix A.

\section{BME Model}

The BME system would receive results from tracer studies from TVE graduates and the industry as input.

\section{Figure 1: BME Model}

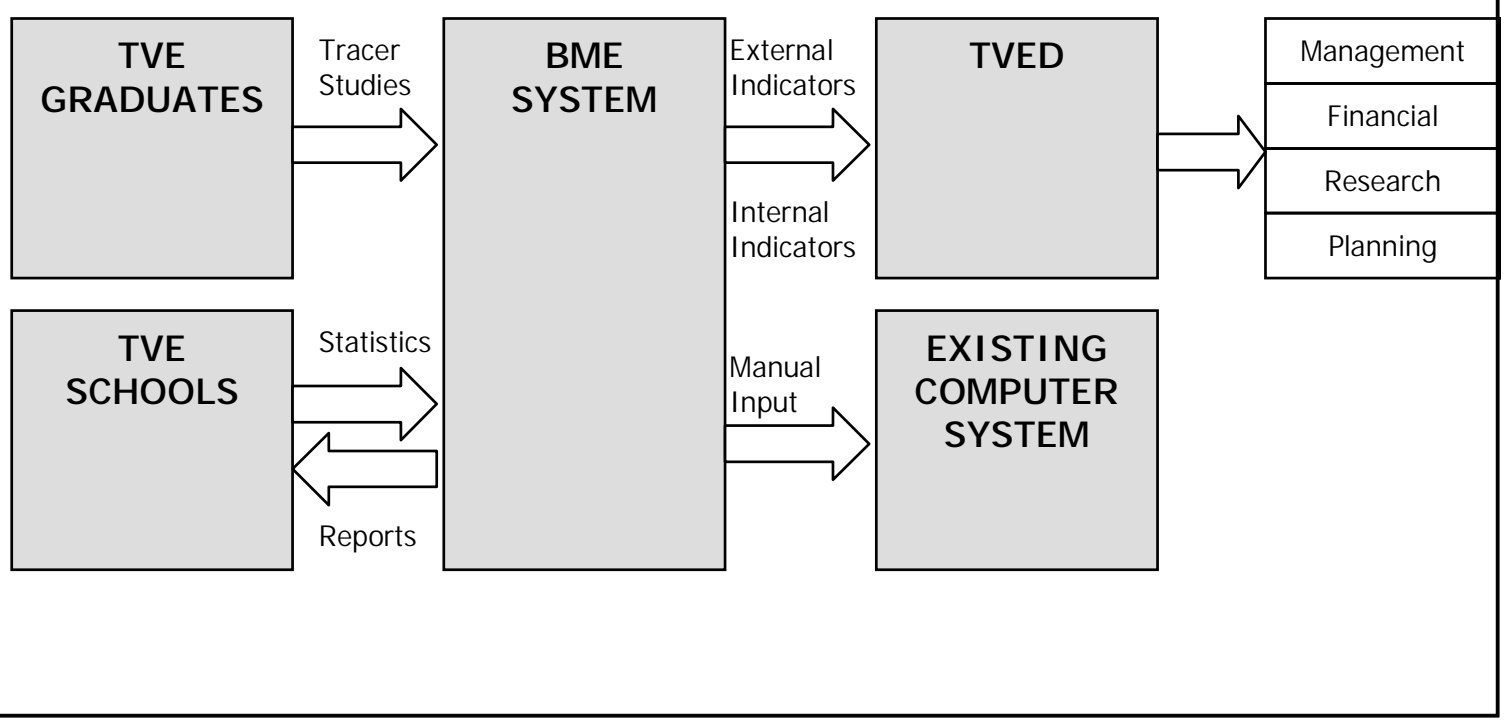


It would also receive statistics from TVE schools as input. Reports are presented to TVED in form of external and internal efficiency indicators.

These reports are also presented to TVE schools. However, results for schools are limited to reports designated to individual school and detailed reports of other schools will not be disclosed. However, statistical reports are accessible by all TVE schools.

Reports from the BME system can also act as input for existing computer systems. However, no online linkages were made in the case of Malaysia. Reports to TVED can be classified into one of the four trust sectors of TVED: management, finance, research and planning. These reports will cater for the data and information needs of respective divisions at TVED. The proposed BME model is depicted in Figure 1.

\section{Design and Implementation of e-BME}

This section will discuss the design and implementation issues of e-BME. Discussions will include the definition and functions of e-BME, conceptual design including components involved, proposed implementation environment, sample reports and analysis of the system.

\section{Definitions and Function}

e-BME is a web-based client server computer application system that supports the implementation of the BME system. It is a system for benefit, monitoring and evaluation of education system especially within the TVED administration. The system will provide support on various processes including input, data manipulation, and output dissemination. TVED is the main user while other MOE departments could benefit much from the system. Most input comes from TVE schools.

All TVE schools will have to interact with the e-BME database via the Internet. Data and other necessary parameters are input into the system from TVE schools but actual data processing will take place at the e-

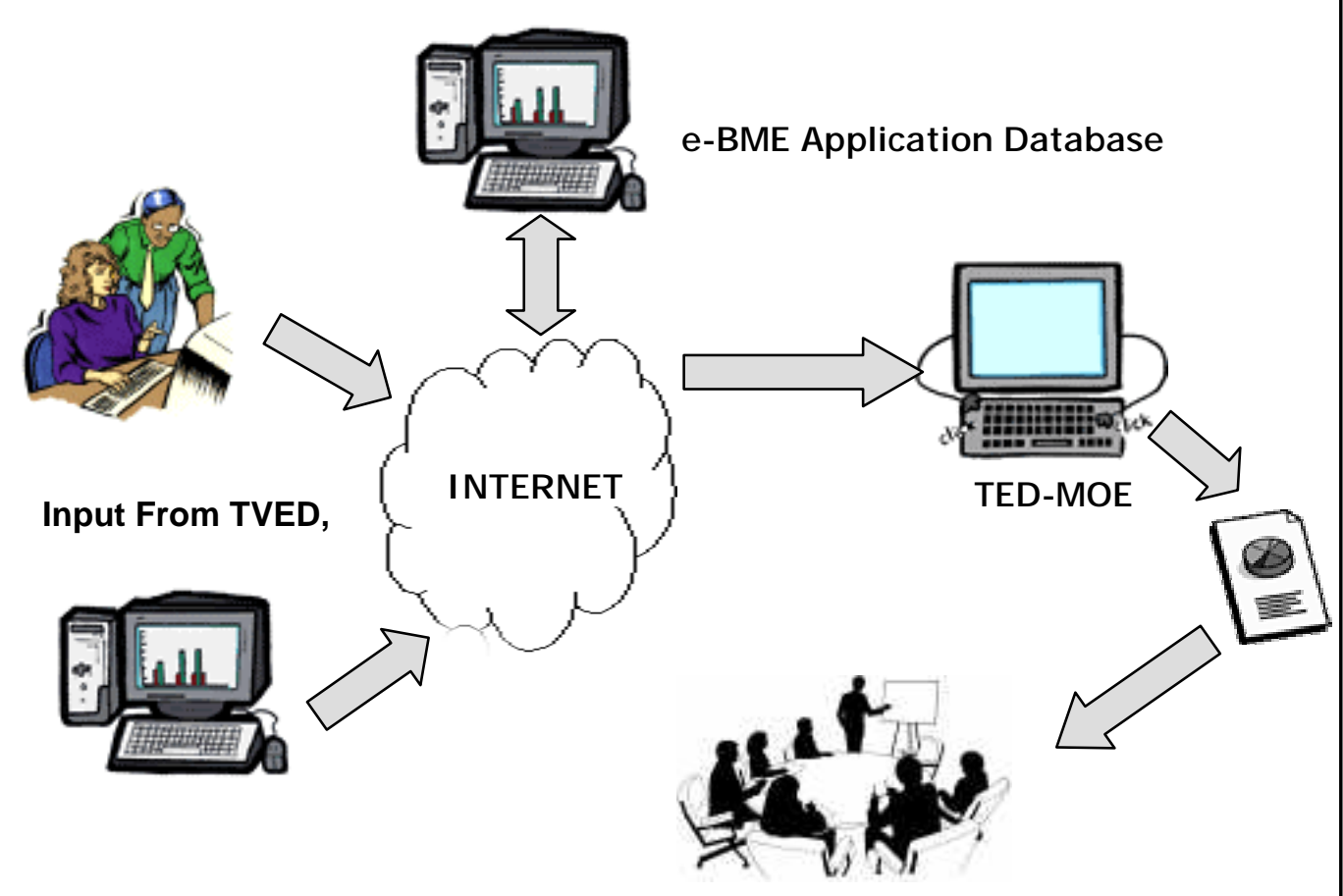

Figure 2: Schematic View Of e-BME Implementation 
BME server. Results will be stored in the database for reporting purposes. Based on a predetermined interval, reports pertaining to the requirements of e-BME will be generated and disseminated. A schematic view of e-BME implementation is depicted in Figure 2.

\section{e-BME Conceptual Design}

e-BME comprises of five components namely e-Pelajar (Student), e-MBME (Management), e-FBME (Finance), e-RBME (Research) and e-PBME (Planning).

e-Pelajar is the core component of e-BME and serves as a basis for establishing input from tracer studies. It can be considered as a basic Student Management Information System where information is obtained as soon as students enroll into TVE schools. Based on this basic record, their academic progress and other relevant information can be monitored and reported.

The e-MBME component is designed for the management division of TVED. Basically, it produces human resource reports and statistics. Example repots would be enrolment by gender and program, professional qualifications of academic staffs and total number of support staffs.

The e-FBME component is designed for the financial division of TVED. As the name implies, e-FBME produces financial reports. Example repots would be total emolument of academic staffs, total cost of equipment maintenance and annual cost per student enrolled.

The e-RBME component is designed for the research division of TVED. It focuses on working graduates. Example repots would be percentage of graduates who are employed within six months after the SPM/SPMV results and percentage of employees who are satisfied with the graduates performance but provide additional training as well.

Finally, the e-PBME component is designed for the planning division of TVED. It deals with the facilities at TVE schools. Example repots would be average classroom capacity used for teaching per semester and average teaching hours per week per full-time teaching staff. The conceptual design of e-BME is depicted

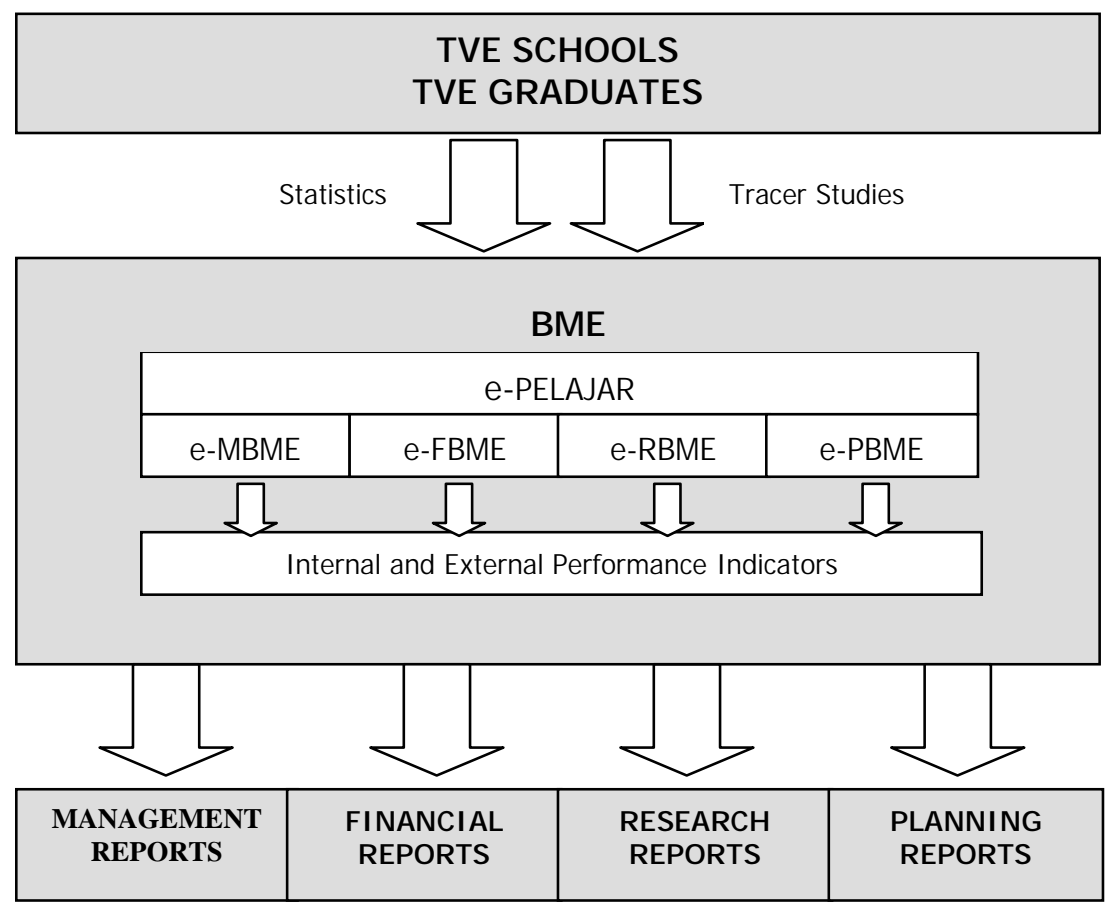

Figure 3: BME Conceptual Design 
in Figure 3.

\section{e-BME Implementation Environment}

e-BME is designated to operate in a web-based environment. As any web application, information storage and hardware configurations are critical and should be carefully implemented. All program files and database are stored in a dedicated server for e-BME located at TVED. This server is connected to the existing network for Internet access. The overall operating environment of e-BME is depicted in Figure 4.

At TVED, the system is accessible by the director of TVED and its divisions. Access to other divisions and departments can be granted based on need and requirement. The director would receive overall reports on the performance of TVE schools for a given academic year.

The Management, Finance, Research and Planning divisions would receive specific repots, suited for individual needs. Financial divisions for example, would receive financial reports necessary in order to monitor its predetermined internal and external efficiency indicators.

At TVE schools, the system is accessible by the headmaster, counselor and registration teacher. Headmasters and counselor can only view reports of his/ her own school. Registration teacher would input and up-

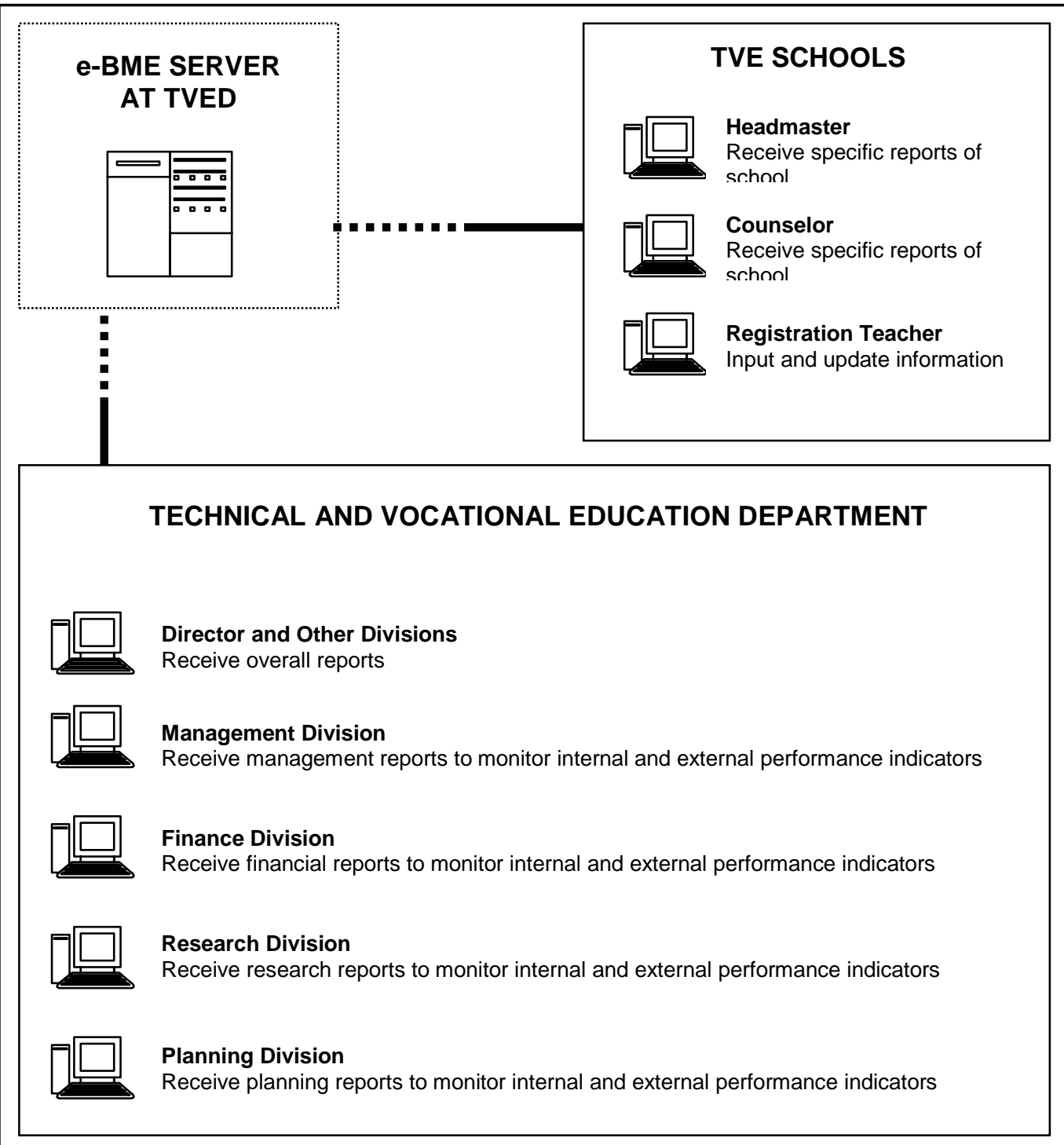

Figure 4: e-BME Operating Environment 
date necessary information regarding his or her school.

\section{Sample Report and Analysis of e-BME}

A training workshop was conducted in October 2001 at the faculty's computer laboratory. Teachers from 20 TVE schools and two officers from TVED participated in the three-day workshop. At the end of training, a survey was administered to identify how well did e-BME meet its requirements and perform required functions. Results of the survey are as follows:

- $52-65 \%$ of the respondents agree that screen attributes (letters, color scheme, layout) were Good and $9-28 \%$ of them rate it Excellence.

- $20-65 \%$ of the respondents agree that the terminology and system's information are Good.

- $20-47 \%$ of the respondents agree that the time taken to learn the system, ease for trial and error, task implementation and message screen used are Good compared to 23-38\% who find them Can Be Improved.

- $23-57 \%$ of the respondents agree that the processing speed, data integrity, information updating feature and the suitability of e-BME for all level of users are Good while $12.5 \%$ rate them Excellence.

Sample reports generated by e-BME can be found in Appendix B.

\section{Conclusion and Future Work}

This paper has discussed the model and design of e-BME, a web-based computer support system for education benefit, monitoring and evaluation. Although the model and system was initially developed for the Malaysian technical education, the open model creates room for adaptations by other education systems.

e-BME is not a complete management information system per se, but it provides a solid foundation for future enhancements and modifications. Much work can be done to improve both the model and system.

e-BME proves to be a powerful management support tool especially in the education system. Reports in the form of internal and external efficiency indicators provide TVED with the information needed for strategic decision-making process. It is hoped that the system meets the need of all users involved if not exceed them.

\section{References}

Ayob Masri \& Sulaiman Hassan. 2001. Technical and Vocational Program Kolej Universiti Teknologi Tun Hussein Onn

(KUITTHO): A New Program for Technical and Vocational Schools, Community Colleges and Polytechnics. Proceedings of Technology and Vocational Technical Education. (2): 358-362.

Ee Ah Meng. 1991. Pedagogi - Suatu Pendekatan Bersepadu. (Pedagogy - An Integrated Approach). Kuala Lumpur: Fajar Bakti Publishers.

Glaser. 1962. Training Research and Education. Pittsburg: University of Pittsburg Press.

Mager, R.F. 1970. Developing Vocational Instruction. Belmont, California: Fearon Publishers.

Mok Soon Sang. 1996. Pendidikan di Malaysia. (Education in Malaysia). Kula Lumpur: Kumpulan Budiman Publishers.

Ramziah Husin \& Ramlee Mustapha. 2001. Impak Globalisasi dan K-ekonomi Terhadap Perancangan Pendidikan Malaysia. (The Impact of Globalization and K-economy Towards Education Planning in Malaysia). Proceedings of Technology and Vocational Technical Education. (2): 240-248.

Ramlee Mustapha, Ruhizan Mohd Yassin, Azhar Abd. Halim \& Hamdan Mohd. Ali. 2001. Globalization And Its Impact On Technical Vocational Education and Training In Malaysia. Proceeding of Technology and Vocational Technical Education.(2): 256-269.

Robiah Sidin. 1994. Pendidikan di Malaysia. (Education in Malaysia). Fajar Bakti Publishers. 
Rouse, C. 1997. Linking Tech. Prep. Programs To Industry Needs. Working paper for Persidangan Kebangsaan Tech. Prep. Technical Education Department, Ministry of Education, Malaysia, Kuala Lumpur, 18-20 Sept.

\section{Biographies}

Prof. Dr. Aziz Deraman is a software engineering professor, specializing in software management and certification. He has held various academic administrative positions and is currently the Dean of the Faculty of Information Science and Technology. Aziz maintains a diverse research interest including IT strategic planning, reusability in multimedia object, e-commerce and e-business implementations and smart education management. His major research, consultancy and development efforts include the development of agriculture portal and e-community program, software certification model and establishing IT strategic planning standards and guidelines for organizations.

Syahrul Fahmy is a Ph.D. research candidate at the Faculty of Technology and Information Sciences, Universiti Kebangsaan Malaysia. His general interests are in the areas of IT strategic planning, software quality and software process certification.

Dr. M. Naim Yaakub is an officer in the Technical and Vocational Education Department, Ministry of Education. He chairs the technical committee overseeing the e-BME project implementation.

Assoc. Prof. Dr. A. Aziz Jemain is an associate professor at the Mathematical Science Center. His area of expertise is in the fields of statistical modeling and problem solving.

\section{Appendix A}

\section{Requirement Definitions}

\section{Examples of Internal Efficiency Indicator}

1. Academic qualifications of teachers by gender.

2. Administrative staff emoluments as a \% of total recurrent cost.

3. Annual cost per student enrolled.

4. Average classroom capacity used for teaching per semester.

5. Average workshop hour used for teaching per semester.

6. Dropout rate by gender.

7. List of working graduates.

8. Total and \% of staff who has had in-service (academic/ professional skill) training/ upgrading.

9. Utilities cost as a $\%$ of total recurrent cost.

10. Working graduates who have gone for training.

\section{Examples of External Efficiency Indicator}

1. Average number of months waiting by graduate for first job.

2. Percentage of employers who are dissatisfied with graduates and provide on-the-job training.

3. Percentage of employers who are satisfied with graduates as they are.

4. Percentage of employers who are satisfied with graduates but provide on-the-job training.

5. Percentage of graduates whose first post-school job employment DOES NOT match training. 


\section{Appendix B \\ Sample Report: e-Pelajar (List of Student by Gender)}

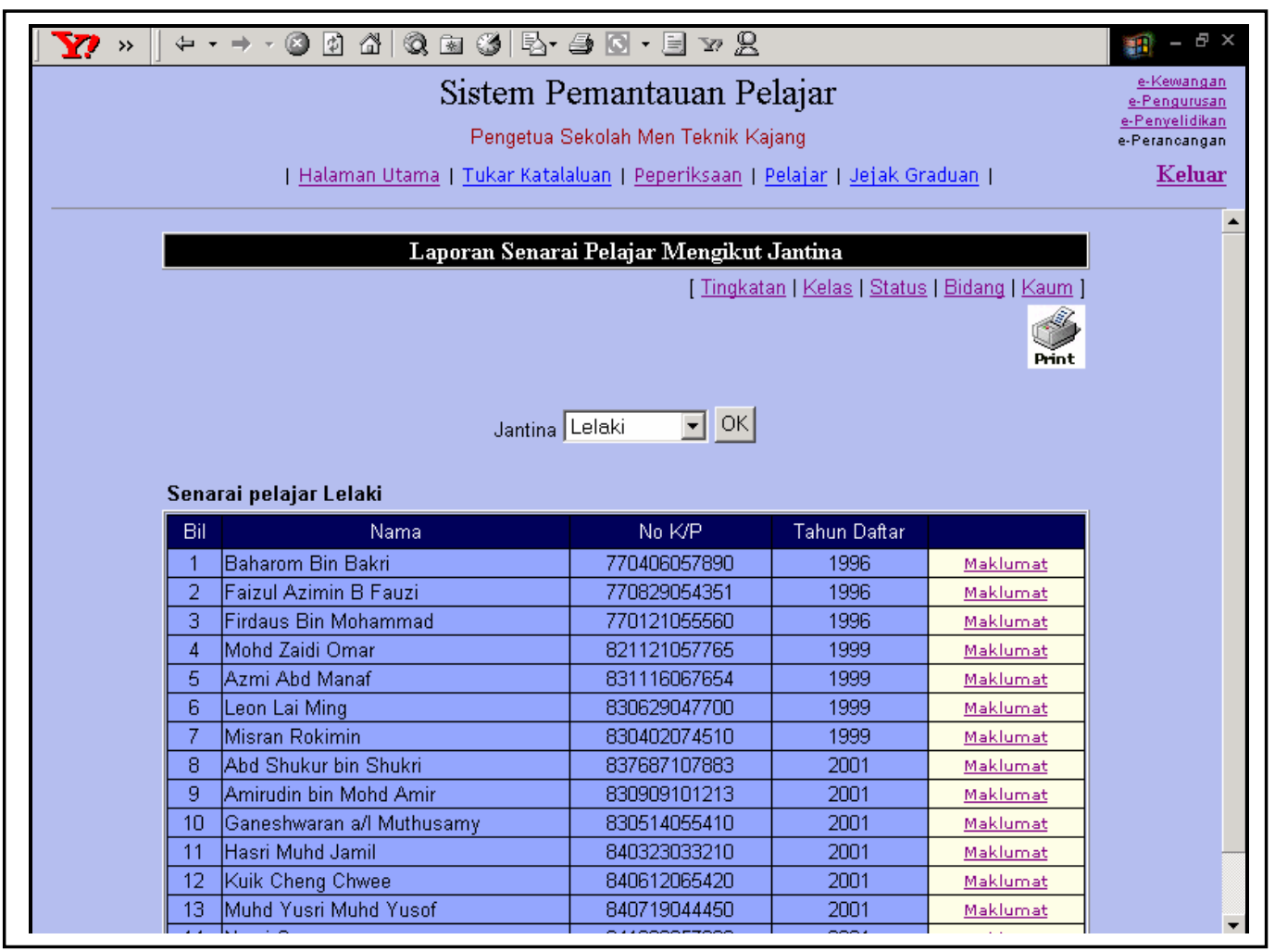

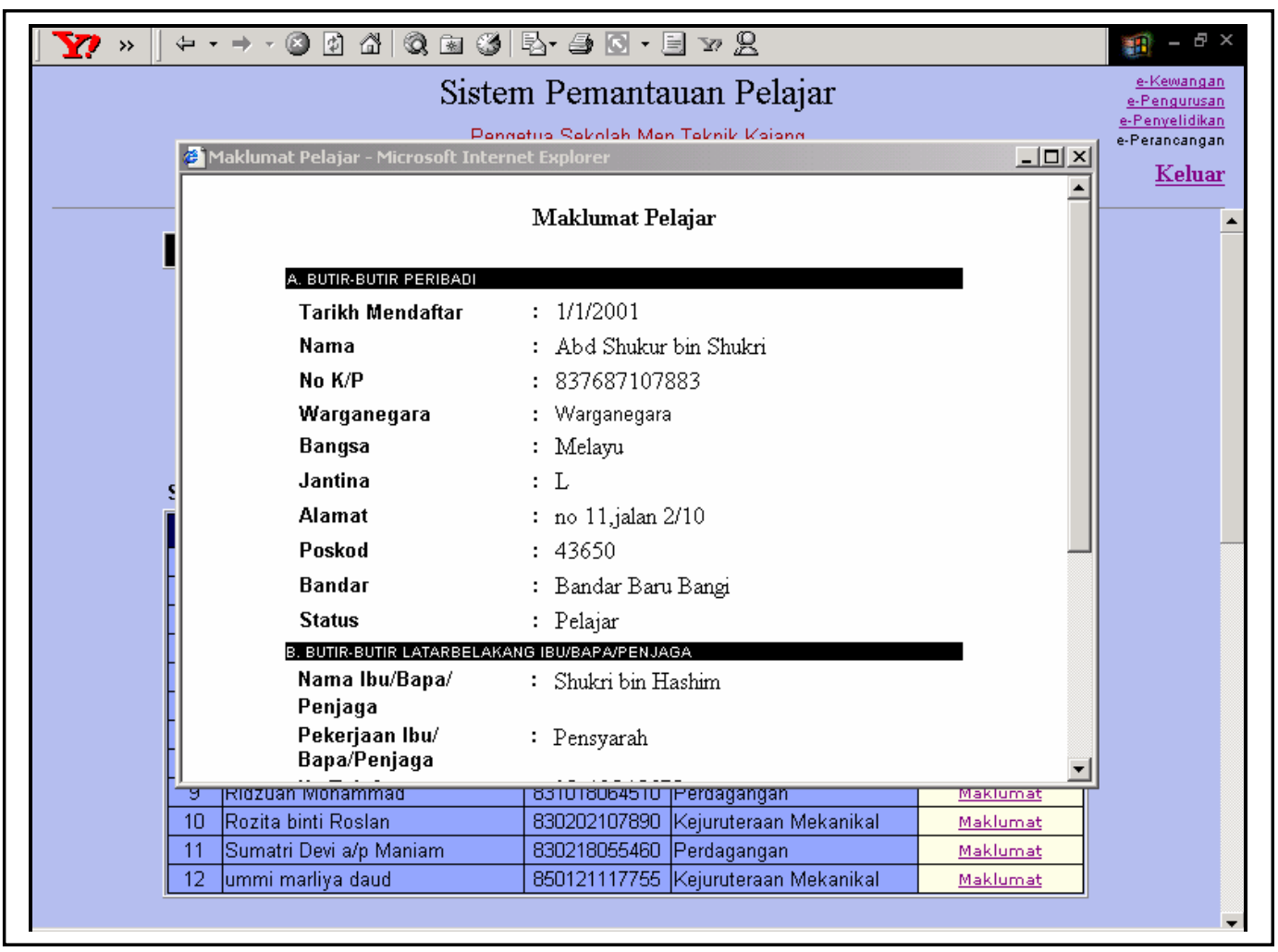

